\title{
PENYELESAIAN KREDIT MACET DENGAN BENDA JAMINAN FIDUSIA YANG DI PALSUKAN (STUDI KASUS: PT. BPR. ULATIDANA RAHAYU)
}

\author{
Ni Made Sintia Tarisa, I Nyoman Putu Budiartha, Ni Made Sukaryati Karma \\ Fakultas Hukum Universitas Warmadewa, Denpasar - Bali, Indonesia
}

\begin{abstract}
Abstrak
Perjanjian merupakan suatu perbuatan hukum yang dilakukan oleh dua orang atau lebih yang memiliki akibat hukum atas hak dan kewajiban bagi para pembuatnya. Perjanjian melibatkan sedikitnya 2 orang atau lebih. Selain orang perorangan, para pihak dalam perjanjian bisa juga terdiri dari badan hukum. Perseroan Terbatas (PT) merupakan badan hukum yang menjadi salah satu pihak atau keduanya dalam perjanjian. Kedua-duanya merupakan subjek hukum, yaitu pihak-pihak yang dapat melakukan perbuatan hukum, pihak-pihak yang mengemban hak dan kewajiban. Mengacu pada permasalahan di atas penelitian ini dilakukan dengan tujuan menggambarkan bagaimana perlindungan hukum terhadap kreditur bank dalam pemberian kredit dengan benda jaminan fidusia yang dipalsukan dan bagaimanakah akibat hukum jika debitur melakukan tindak pidana pemalsuan BPKB jaminan kredit. Penelitian ini didesain dengan menggunakan pendekatan penelitian empiris. Hasil penelitian ini menunjukkan bahwa perlindungan hukum terhadap kreditur bank dalam pemberian kredit dengan benda jaminan fidusia yang dipalsukan diatur dalam pasal 1131 dan 1132 KUHPerdata. Perlindungan hukum lain yang diberikan kepada kreditur adalah perlindungan hukum secara preventif yang merupakan perlindungan hukum pencegahan terjadinya sengketa dan dalam hal ini yang menyangkut hak dan kewajiban kreditur. Hasil lain dari penelitian ini adalah debitur yang memalsukan objek jaminan atau BPKB kendaraan yang digunakan untuk jaminan kredit di kenakan pasal 263 KUHP dengan ancaman hukuman pidana penjara paling enam tahun. Jadi, perlindungan hukum maupun sanksi kepada kreditur dan debitur jika terjadi permasalahan sudah diatur dalam Peraturan Perundang-Undangan.
\end{abstract}

Kata kunci: Jaminan Fidusia, Kredit Macet, Pemalsuan, Perlindungan Hukum

\begin{abstract}
An agreement is a legal action carried out by two or more people who have legal consequences for the rights and obligations of the makers. The agreement involves at least 2 or more people. In addition to individuals, the parties to the agreement may also consist of legal entities. Limited Liability Company $(P T)$ is a legal entity that is one of the parties or both of them in the agreement. Both are legal subjects who can carry out legal actions and carry out their rights and obligations. Referring to the above problems, this study was conducted with the aim of describing how the legal protection of bank creditors in granting credit with fiduciary collateral objects falsified and how the legal consequences if the debtor commits the fraud of the BPKB (certificate of ownership of motor vehicles) credit guarantee. This research was designed using an empirical research approach. The results of this study indicated that the legal protection of bank creditors in falsifying collateral loans with fiduciary collateral objects is regulated in articles 1131 and 1132 of the Civil Code. Other legal protection given to creditors is preventive legal protection which is legal protection to prevent disputes and in this case concerning the rights and obligations of creditors. Another result of this research is the debtor who falsified the collateral object or the BPKB of the vehicle that was used for credit guarantees was used in article 263 of the Criminal Code with the threat of a maximum prison sentence of six years. So, legal protection and sanctions to creditors and debtors, if a problem occurs is regulated in statutory regulation.
\end{abstract}

Keywords: Fiduciary Guarantee, Bad Credit, Counterfeiting, Legal Protection

\section{PENDAHULUAN}

Pertumbuhan ekonomi sebagai bagian dari pembangunan nasional merupakan salah satu upaya untuk mecapai masyarakat yang adil dan makmur berdasarkan pancasila dan Undang-Undang Dasar Negara Republik Indonesia tahun 945. Pembangunan ekonomi dalam hal ini sangat diperlukan untuk terus meningkatkan dan menciptakan stabilitas perekonomian yang lebih baik, sehingga diperlukan suatu kerja sama yang baik antara pemerintah dan masyarakat baik perorangan maupun badan hukum. Suatu kerjasama yang dilakukan antara pemerintah dan masyarakat tentunya memerlukan Dana yang 
besar agar terciptanya suatu pertumbuhan ekonomi yang bagus. Kebutuhan akan dana tersebut dapat diperoleh melalui perjanjian pinjam meminjam kredit.

Salah satu pelayanan jasa pihak perbankan terhadap masyarakat, yaitu perbankan memfasilitasi peminjaman dengan peminjaman kredit menggunakan jaminan benda begerak maupun benda tidak bergerak. Berdasarkan kesepakatan kedua belah pihak yang mewajibkan pihak peminjam untuk melunasi utangnya setelah jangka waktu tertentu dengan pemberian bunga. Berdasarkan undangundang NRI 10 tahun 1998 perubahan atas undang-undang Negara Republik Indonesia 7 tahun 1997 tentang perbankan pada pasal 1 ayat 11 .

Perjanjian merupakan suatu perbuatan hukum yang dilakukan oleh dua orang atau lebih yang memiliki akibat hukum atas hak dan kewajiban bagi para pembuatnya (Haryanto, 2010; Sinaga, 2018). Dalam suatu perjanjian meliputi kegiatan (prestasi). Perjanjian melibatkan sedikitnya 2 pihak yang saling memberikan kesepakatan mereka. Dalam perjanjian kredit di bank pihak yang berkewajiban memenuhi isi perjanjian disebut debitur, sedangkan pihak lain yang berhak atas pemenuhan kewajiban itu disebut kreditur.

Pemberian kredit oleh bank kepada nasabah/debitur dilakukan secara berkesinambungan untuk mengumpulkan keuntungan maupun membiayai seluruh kegiatan oprasional. Pelepasan kredit oleh pihak bank juga didasari pertimbangan unsur prestasi. Hal ini dapat diartikan bahwa setiap kesepakatan yang terjadi antara pihak bank (kreditur) oleh debitur, mengenai suatu perjanjian kredit, maka pada saat itu juga terjadinya suatu prestasi atau kontrak prestasi (Gozali, 2007).

Dalam praktek perbankan terutama pada Bank Perkreditan Rakyat yang sebagian besar nasabahnya Usaha Menengah Kebawah atau menengah kebawah, jaminan yang dianggap paling aman dan paling ideal untuk mencegah risiko adalah jaminan kebendaan. Jaminan tersebut dapat berbentuk benda bergerak (gadai dan fidusia) maupun benda tetap (hak tanggungan). Bank memberikan kredit dengan jaminan materiil menggunakan jaminan fidusia untuk angunan benda bergerak dan jaminan hak tanggungan untuk jaminan benda tidak bergerak. Karena debitur meminjam kredit dengan pinjaman yang tidak terlalu besar, sehingga jaminan yang lebih dominan yaitu benda bergerak dengan menggunakan lembaga fidusia.

Jaminan benda bergerak yaitu fidusia. Pengaturan jaminan fidusia dapat dilihat dalam UU NRI 42 tahun 1999 tentang jaminan fidusia, dan perikatan pembebanan jaminan fidusia dibuat dengan akta Notaris. Jaminan Fidusia merupakan jaminan kebendaan atas benda bergerak baik yang berwujud maupun tidak berwujud sehubungan dengan hutang-piutang antara debitur dan kreditur. Jaminan fidusia diberikan oleh debitur kepada kreditur untuk menjamin pelunasan hutangnya. Fidusia memberikan pengalihan hak kepemilikan suatu benda atas dasar kepercayaan dengan ketentuan bahwa benda yang hak kepemilikannya dialihkan tetap dalam penguasaan pemilik benda (Kumaladewi, 2015; Setiono, 2018).

Perjanjian fidusia dilakukan antara kreditur dengan debitur yang menjaminkan suatu jaminan berupa benda bergerak kepada kreditur. Jika dalam proses pembayaran terjadinya wanprestasi oleh debitur terhadap kreditur, maka Eksekusi jaminan fidusia dapat dilakukan jika debitur (pemberi fidusia) cidera janji atau tidak memenuhi prestasi tepat waktu, walaupun telah diberikan somasi.

Dalam melakukan perjanjian selain memenuhi syarat sahnya perjanjian yang diatur dalam pasal 1320 KUHP, kedua belah pihak yang melakukan perjanjian harus berdasarkan itikad baik sebagai landasan seseorang melakukan perbuatan hukum dalam membuat suatu perjanjian. Dalam unsur itikad baik yang paling utama yaitu kejujuran. Kejujuran dari keduabelah pihak dalam melakukan perjanjian. Karena ketidak jujuran dalam melakukan perjanjian dari salah satu pihak dapat merugikan pihak satunya. Sama halnya dalam kasus yang terjadi di PT. BPR.Ulatidana Rahayu yang mana salah satu pihak yaitu debitur yang melanggar syarat sahnya perjanjian karena tidak melaksanakan prestasinya dan selain itu debitur ini melakukan pemalsuan BPKB yang dijadikan objek jaminan.

Mengacu pada latar belakang yang diuraikan diatas, permasalahan yang akan dibahas dalam penelitian ini adalah bagaimana perlindungan hukum terhadap kreditur bank dalam pemberian kredit dengan benda jaminan fidusia yang dipalsukan dan bagaimanakah akibat hukum jika debitur melakukan tindak pidana pemalsuan BPKB jaminan kredit.

\section{METODE PENELITIAN}

Penelitian ini didesain menggunakan pendekatan penelitian empiris yaitu bertumpu pada sifat hukum yang nyata atau sesuai dengan kenyataan yang hidup di masyarakat. Pendekatan sosiologis hukum 
merupakan pendekatan yang digunakan untuk melihat aspek-aspek hukum dalam interaksi sosial didalam masyarakat, dan berfungsi sebagai penunjang untuk mengidentifikasi dan mengklarifikasi temuan bahan hukum bagi keperluan penelitian atau penulisan hukum. Data dalam penulisan skripsi ini diperoleh dari dua sumber, yaitu data yang diperoleh secara langsung dari masyarakat yang dinamakan data primer dan diperoleh dari bahan-bahan pustaka dinamakan data sekunder. Adapun data yang dipergunakan dalam penelitian ini diperoleh dari 2 ( dua ) sumber data. Data primer yaitu data yang diperoleh secara langsung dari objeknya, guna mendapat data lapangan. Data primer dikumpulkan melalui wawancara dengan informan. Sedangkan data sekunder Data sekunder adalah Data yang diperoleh dari peraturan perundang-undangan maupun pendapat-pendapat para sarjana hukum dan buku-buku atau tulisan-tulisan ilmiah yang berkaitan dengan permasalahan. Penelitian ini yang dilakukan di PT. BPR. ULATIDANA RAHAYU yang beralamat di Jl. Prof. Dr. Ib. Mantra No.77x Sukawati, Gianyar. Setelah seluruh data terkumpul, adapun langkah selanjutnya, yaitu melakukan pengklarifikasian secara cermat dan dianalisis secara deskriftif kualitatif, dan pada akhirnya disajikan secara sistematis berupa deskripsi.

\section{HASIL PENELITIAN DAN PEMBAHASAN Perlindungan Hukum terhadap Kreditur Bank dalam Pemberian Kredit dengan Benda Jaminan Fidusia yang Dipalsukan}

Kredit macet merupakan kredit bermasalah. Kredit bank yang bermasalah mengakibatkan bank tersebut menghadapi risiko usaha bank. Jenis risiko kredit (default risk) yaitu risiko akibat ketidak mampuan debitur mengembalikan pinjaman yang diterimanya dari bank beserta bunganya sesuai dengan jangka waktu yang telah ditentukan. Kredit bermasalah selalu ada dalam kegiatan perkreditan bank karena bank tidak mungkin menghindari adanya kredit bermasalah. Bank harus berusaha menekan seminimal mungkin besarnya kredit bermasalah agar tidak melebihi ketentuan Bank Indonesia sebagai pengawas perbankan (Sutarno, 2005).

Berdasarkan hasil wawancara dengan Bapak I Made Suarja selaku Direktur Utama di PT. BPR. Ulatidana Rahayu, yang menerangkan bahwa sesuai regulasi yang mengatur yaitu Paket kebijakan deregulasi bulan Mei tahun 1993 (PAKMEI 1993), di Indonesia ada dua golongan kredit bank, yaitu kredit lancar dan kredit bermasalah. Dimana yang dikatakan kredit bermasalah digolongkan menjadi 3 (tiga), yaitu:

1. Kredit kurang lancar

2. Kredit diragukan

3. Kredit macet.

Golongan kredit macet merupakan risiko yang paling dikhawatirkan oleh bank karena dapat mengganggu kondisi keuangan bank, bahkan dapat mengakibatkan berhentinya usaha bank. Upaya atau langlah-langkah yang dilakukan untuk menangani kredit macet atau bermasalah, adapun tiga langkah yang harus dilaksanakan yang pertama pembinaan, yang ke dua Nonlitigasi (ADR), dan Litigasi. Untuk mengantisipasi hal tersebut di atas dan kredit dapat kembali sesuai dengan perjanjiannya. Maka proses pencairan kredit harus memperhatikan tahapan- tahapan yang disebut dengan siklus manajement perkreditan antara lain. Penanggulangan risiko diawali sejak identifikasi subjek hukum dari permohonan kredit, tujuan kredit, jaminan kredit dan lainnya.

Proses kredit merupakan proses yang dinamis dan dilakukan secara end to end. Proses kredit secara umum yang terdiri dari tahapan inisiasi kredit, verifikasi, analisis, dokumentasi, monitoring, dan penyelesaian kredit. Dalam pelaksanaanya harus memperhatikan prinsip kehati-hatian dan karakteristik masing-masing segmen kredit (Ikatan Bankir Indonesia (IBIS), 2014).

Proses pemberian kredit di PT.BPR.Ulatidana Rahayu sesuai wawancara dengan Ibu Ni Luh Gede Padma Wati selaku direktur PT.BPR. Ulatidana Rahayu, mengatakan bahwa mengenai tahaptahap pemberian kredit:

1. Permohonan kredit

2. Analisa Kredit

3. Keputusan kredit/Komite

4. Administrasi Kredit

5. Pemantauan dan Pembinaan Kredit

6. Penanganan Kredit Bermasalah 
Proses pengeluaran kredit secara umum maupun di PT.BPR Ulatidana Rahayu tidak berbeda. Yang membuat berbeda adalah kebijakannya karena kebijakan di setiap bank berbeda-beda. Di PT. BPR Ulatidana Rahayu dengan BPR lain mengenai kebijakan presentase bunga sampai kebijakan jangka waktu pembayaran dan cara pelayanan nasabahnya memiliki perbedaan.

Memperhatikan besarnya risiko pemberian kredit kepada debitur. Pihak kreditur juga harus merangkai atau melandasi setiap proses pemberian kredit agar aman dan mempunyai dasar hukum yang jelas mengingat tidak ada Undang-Undang kusus yang mengatur perlindungan kreditur. Maka dari itu pihak kreditur harus mendasari kegiatanya berdasarkan ketentuan-ketentuan yang berlaku.

Perlindungan hukum dapat dibagi menjadi dua yaitu perlindungan hukum internal dan perlindungan hukum eksternal. Perlindungan hukum internal yaitu dimana perlindungan hukum yang dibuat sendiri oleh para pihak pada saat membuat perjanjian, dalam hal ini antara debitur dan kreditur. Disamping itu pengertian perlindungan hukum eksternal, dimana perlindungan yang dibuat oleh penguasa yaitu kreditur melalui regulasi atau pengaturan bagi kepentingan pihak yang lemah. Dengan demikian hukum sesuai hakikat aturan perundang-undangan yang tidak bersifat memihak. Sehingga secara proposional juga wajib diberikan perlindungan hukum yang seimbang (Semadiartha, 2019). Selain faktor eksternal maupun internal diupayakan juga perlindungan preventif merupakan pencegahan terjadinya sengketa dan perlindungan represif merupakan penyelesaian masalah dengan pemberian sanksi.

Dalam melakukan perjanjian kredit seorang debitur harus memenuhi persyaratan dari pihak bank. Salah satu persyaratannya yaitu memberikan jaminan sebagai objek perjanjian. Hal ini bertujuan untuk memberikan keyakinan kepada pihak bank agar kredit yang diberikan kepada pihak debitur dapat diterima kembali sesuai dengan syart-syarat perjanjian yang disepakati antara kedua belah pihak yaitu kreditur dan debitur.

Perlindungan hukum secara preventif yaitu perlindungan hukum pencegahan terjadinya sengketa dan dalam hal ini yang menyangkut hak dan kewajiban kreditur. Suatu perikatan dapat melahirkan hak dan kewajiban dalam sebuah perjanjian. Dalam suatu perjanjian kredit yang diatur dalam Pasal 1131 dan 1132 KUHPerdata secara tegas diatur tentang perlindungan hukum terhapap kredit. Pasal 1131 ini bahwa pihak bank akan mendapat perlindungan hukum bilamana debitur wanprestasi dan tidak dapat melaksanakan kewajiban yang harus dilakukan maka segala harta bendanya baik yang sudah ada maupun yang akan ada di kemudian hari terlebih yang dijadikan jaminan kredit dapat dibebankan eksekusi untuk dilelang dan dari hasil penjualan akan dipakai untuk membayar tunggakan maupun kewajiban debitur. Pasal 1132 ini secara sepesifik disebutkan bahwa benda yang dijadikan jaminan kredit akan diutamakan hasil eksekusinya untuk yang memegang jaminan secara prioritas dan atau diutamakan.

Perlindungan hukum represif yaitu perlindungan hukum yang bersifat menyelesaikan sengketa dengan memberi sanksi. Jika pihak debitur melanggar perjanjian atau wanprestasi, harus ada ganti rugi sebagia sanksi terhadap debitur. Jika debitur melakukan pemalsuan BPKB, maka debitur akan di jatuhi hukuman yang diatur dalam pasal 263 KUHP. Jika debitur melakukan pemalsuan objek jaminan maka pihak bank dapat menuntut secara perdata dan selanjutnya secara pidana. Karena pemalsuan termasuk tindak pidana yang diatur dalam pasal 263 KUHP.

Selain penyelesaian kredit macet, pihak kreditur atau pihak bank perlu perlindungan hukum guna melindungi hak-hak pihak kreditur jika terbukti bahwa pihak debitur yang melakukan kesalahan. Sebaliknya, jika pihak kreditur yang melakukan kesalahan atau ingkar janji, maka pihak debiturlah yang dilindungi oleh undang-undang perlingdungan konsumen yang diatur dalam UU NRI 8 tahun 1999 karena debitur merupakan seorang konsumen yang harus mendapat perlindungan jika merasa dirugikan oleh pihak produsen atau bank.

\section{Akibat Hukum jika Debitur Melakukan Tindak Pidana Pemalsuan BPKB Jaminan Kredit}

Proses verifikasi sangatlah penting karena verifikasi itu merupakan suatu langkah yang dilakukan untuk meyakinkan apakah suatu objek itu benar asli, atau mencocokan kembali secara fisik dengan dokumen yang ada, dan dokumen yang ada di cocokan keabsahannya. Berdasarkan hasil wawancara dengan Bapak Nyoman Parta selaku Kepala Bagian Kredit di PT. BPR Ulatidana Rahayu pada hari kamis tanggal 12 Desember 2019, mengatakan bahwa proses identifikasi dan verifikasi data jaminan dan fisik jaminan yang akan dipakai anggunan atau jaminan kredit adapun uraian tugasnya sebagai berikut: 
1. Berawal dari menerima blangko permohonan kredit yang diajukan oleh calon debitur.

2. Melakukan verifikasi terhadap hasil SLIK calon nasabah baik itu permohonan, penanggungan dan penjaminan.

3. Melakukan ceking atas permohonan kredit yang diajukan oleh calon debitur, yang meliputi:

a. Identitas debitur maupun identitas penjamin

b. Tempat tinggal dan atau status tempat tinggal

c. Tempat dan jenis usaha calon debitur

d. Sumber-sumber penghasilan yang akan dipergunakan untuk melakukan pembayaran kembali pinjaman yang di terima.

e. Karakter calon debitur

4. Melakukan analisa atas ceking yang telah dilakukan dengan menggunakan metode $5 \mathrm{c}$ dengan menggunakan pendekatan repayment capasity approach, character approach, collateral approach, capital, condition of economy.

5. Mengadakan pemeriksaan langsung (fisik) terhadap barang jaminan,

6. Mengecek keabsahan surat-surat barang jaminan,

7. Mencocokan fotocopy jaminan kredit dengan aslinya,

Jika semua dokumen tersebut telah klir atau bersih dari semua pembebanan barulah bisa dipertimbangkan sebagai jaminan kridit di bank.

Selain verifikasi terhadap bukti kepemilikan jaminan / BPKB juga dilakukan verifikasi terhadap:

a. Faktur kendaraan

b. Kwitansi kosong dan kwitansi jual-beli atas nama kendaraan

c. Fotocopy kartu tanda penduduk (KTP) atas nama pemilik kendaraan

d. Foto jaminan sebagai bukti melengkapi data verifikasi

Masih berkaitan dengan jaminan kredit benda bergerak bank juga harus melakukan taksasi nilai jaminan tersebut untuk bisa dipertimbangkan mengenai maksimal besaran kredit yang layak bisa dibantu.

Pentingnya proses verifikasi di dalam pengeluaran kredit untuk mencegah atau memitigasi risiko-risiko yang akan muncul nantinya. Risiko yang dapat menghambat atau merugikan salah satu pihak debitur maupun pihak kreditur. Timbulnya kredit bermasalah tidak semata-mata disebabkan karena ketidakmampuan debitur melaksankan kewajibannya melainkan juga disebabkan karena ketidak mauan debitur untuk membayar utangnya. Ketidakmauan tersebut diakibatkan karena didasari oleh karakter nasabah yang tidak mau membayar utang dan memang ada niat yang sengaja dikemas untuk melakukan penipuan. Akhir-akhir ini sering marak terjadi kejatan di sektor perbankan yang dapat merugikan bank dan mengurangi kepercayaan terhadap masyarakat luas. Selain kasus wanprestasi yang sering kali terjadi adapun kasus lain yang akhir-akhir ini timbul yaitu kasus pemalsuan dokumen yang dilakukan oleh debitur. Selain itu niat jahat yang bisa saja timbul karena terdesak atau merasa kepepet, debitur bisa saja melakukan pemalsuan dokumen jaminan atau BPKB sebgai objek jaminan.

Perbuatan pemalsuan merupakan suatu tindakan seseorang yang memberikan gambaran atas suatu barang atau Surat seolah-olah asli atau benar. Perbuatan ini bisa juga dikatakan sebagai tindakan menipu atau memperdaya orang lain dengan sebisa mungkin mengkondisikan suatu yang tidak benar atau tidak asli, sehingga orang lain percaya dan terpedaya (Wibawa, 2002).

Tindak pidana pemalsuan sebagai mana diatur dalam kitab undang-undang hukum pidana pasal 263 sampai pasal 276 KUHP. Semua tindakan atau langkah yang dilakukan oleh pelaku perbuatan melawan hukum dengan tujuan untuk menyamarkan atau membuat atau sebagai mirip seperti bentuk aslinya, semuanya itu diawali dengan niat jahat seorang pelaku atau disebut mens rea.

Unsur melawan hukum dan kesalahan bentuk sengaja merupakan unsur mutlak yang bisa ada secara terselubung, tidak dengan mengenai unsur objek tindak pidana. Hal ini selalu dicantumkan di dalam rumusan. Perbuatan selalu dikaitkan dengan objek tindak pidana yang sekaligus merupakan objek perbuatan. Karena perbuatan selalu diarahkan pada objek. Kedua unsur ini tidak dapat dipisahkan, bahkan sering menyatu. Objek diletakkan dibelakang unsur tingkah laku (Chazawi \& Ferdian, 2014).

Pada kasus yang terjadi di PT. BPR Ulatidana Rahayu debitur yang menggunakan BPKB palsu sebagai objek jaminan dalam peminjaman kredit. Pelaku yang awalnya teridentifikasi pada saat debitur ini tidak melaksanakan kewajibannya. Setelah dilakukan verifikasi terhadap dokumen 
jaminan, pihak kepolisian atau pihak berwajib menyatakan bahwa dokumen itu palsu sehingga pihak bank memberikan kesempatan terhadap debitur untuk menyelesaikan permasalahan tersebut secara nonlitigasi, akan tetapi tenggang waktu tersebut tidak dimanfaatkan oleh debitur. Oleh karena itu, pihak bank melakukan proses litigasi dengan melakukan pelaporan kepihak yang berwajib. Setelah itu debitur ditetapkan sebagai terpidana atas tuduhan melakukan tindak pidana pemalsuan Buku Pemilik Kendaraan Bermotor (BPKB) yang menyebabkan pihak bank mengalami kerugian.

\section{SIMPULAN DAN SARAN}

\section{Simpulan}

Berdasarkan hasil penelitian yang dipaparkan di atas, ada beberapa simpulan yang dapat dibuat, yaitu: pertama, Perlindungan hukum terhadap kreditur bank dalam pemberian kredit dengan benda jaminan fidusia yang dipalsukan, bank telah melaksanakan prisnsip kehati-hatian dalam pemberian kredit. Namun tidak semua debitur jujur dalam memberikan informasi yang sebenarnya, sehingga dapat menimbulkan kasus dalam perjanjian kredit yang akhirnya dapat menyebabkan kerugian terhadap pihak bank. Oleh karena itu, agar kreditur atau pihak bank mendapat perlindungan hukum, maka setiap membuat perjanjian haruslah memenuhi syarat sahnya perjanjian dimana syarat sahnya perjanjian diatur dalam pasal 1320 KUHPerdata. Kedua, akibat hukum jika debitur melakukan tindak pidana pemalsuan BPKB jaminan kredit adalah akan di kenakan pasal 263 KUHP dengan ancaman hukuman pidana penjara paling enam tahun.

\section{Saran}

Adapun saran yang disampaikan penulis berkaitan dengan penelitian ini, yaitu bagi pemerintah, diperlukan adanya regulasi untuk pembentukan aturan oleh pemerintah terkait tentang perlindungan hukum terhadap pihak kreditur demi memberikan perlindungan dan kepastian hukum terhadap pihak kreditur, kedua masyarakat, khususnya pihak bank sebagai pemberi kredit dapat menerima atau menolak nasabah kredit baru sehubungan dengan hasil prediksi prilaku nasabah (treck Records).

\section{DAFTAR PUSTAKA}

Chazawi, A., \& Ferdian, A. (2014). Tindak Pidana Pemalsuan: Tindak Pidana yang Menyerang Kepentingan Hukum Terhadap Kepercayaan Masyarakat mengenai Kebenaran Isi Tulisan dan Berita yang Disampaikan. Jakarta: PT Rajawali Pers.

Gozali, I. (2007). Manaje Risiko Perbankan. Semarang: Badan Penerbit Universitas Diponegoro.

Haryanto, T. D. (2010). Hubungan Hukum yang Menimbulkan Hak dan Kewajiban dalam Kontrak Bisnis. Wacana Hukum, IX(1), 85-97.

Ikatan Bankir Indonesia (IBIS). (2014). Mengelola Kredit Secara Sehat. Jakarta: PT. Gramedia Pustaka Utama.

Kumaladewi, N. A. (2015). Eksekusi Kendaraan Bermotor sebagai Jaminan Fidusia yang Berada pada Pihak Ketiga. Jurnal Repertorium, II(2).

Semadiartha, I. N. (2019). Penyelesaian Kredit Bermasalah (Eksekusi Hak Tanggungan Secara Online Bank Perkreditan Rakyat). Malang: PT. Cita Intrans Selaras.

Setiono, G. C. (2018). Jaminan Kebendaan dalam Proses Perjanjian Kredit Perbankan (Tinjauan Yuridis Terhadap Jaminan Benda Bergerak Tidak Berwujud). Transparansi Hukum, 1(1), 1-18.

Sinaga, N. A. (2018). Peranan Asas-Asas Hukum Perjanjian dalam Mewujudkan Tujuan Perjanjian. Binamulia Hukum, 7(2), 107-120.

Sutarno. (2005). Aspek-aspek HukumPerkreditan pada Bank. Jakarta: Alfabeta.

Wibawa, H. K. (2002). Verifikasi Dokumen dan Tanda Tangan Pencegahan dan Penindakan Kejahatan Perbankan dan Keuangan (I). Jakarta: PT. Gramedia Pustaka Utama. 